\title{
訂正
}

Akiyama, K., \& Morimoto, K. (2015). The Development of the Teaching Materials for Evolution in High School Biology in Cambodia. Journal of Research in Science Education, 55(4), 397-404.

におきまして, 和文要約（日本語の論文題目, 著者氏名, 所属, 要約, キーワード）が落 丁しておりましたので，追加訂正いたします。誌面につきましては，次頁のようになりま すので, ご利用下さい。なお, J-STAGE 上の訂正記事では, 該当論文の全頁の PDF をご 利用頂けます。

著者ならびに関係者の皆様にお詫びを申し上げるととともに，追加訂正いたします．

日本理科教育学会「理科教育学研究」編集委員会 


\title{
カンボジアの高等学校生物における進化の教材開発
}

\author{
秋山兼太郎 ${ }^{1}$ \\ 森本 弘一 ${ }^{2}$
}

\begin{abstract}
【要
約】

カンボジアの新教育課程では, 高等学校生物において, 進化の内容が新しく導入された。 この論文は, カンボジアの高等学校生物における進化の教材を開発したことを報告するもの である。この開発した教材は, カンボジアで通常食べられているアヒルの卵の教材化を含ん でいる。開発した教材の有効性は, カンボジアの大学生を対象とした授業で検証された。得 られた知見は下記の通りである。

(1) 恒温器を用いてアヒルの卵の発生の様子を観察することができる。

（2）カンボジアの生物教育における進化に対する新しい教材を開発した。

（3）この教材を学習した学生たちは, この教材に興味を持ち, 進化に対して理解を深めた。 以上のように, 本研究で開発した教材は, 進化を学習するのに有効であると結論付けた。

[キーワード] 進化, カンボジア，教材
\end{abstract}

1 大阪府立山本高等学校

2 奈良教育大学 


\title{
Original Paper
}

\section{The Development of the Teaching Materials for Evolution in High School Biology in Cambodia}

\author{
Kentaro AKIYAMA ${ }^{1}$, Koichi MORIMOTO ${ }^{2}$
}

【Summary】

\begin{abstract}
The subject of evolution has been newly introduced to high school biology classes in Cambodia as part of a new national curriculum. This study reports on the development of teaching materials for teaching evolution in high school biology classes in Cambodia. These developed teaching materials utilize a duck embryo, which is commonly eaten in Cambodia as pong tia koon. The effectiveness of the developed teaching materials was examined by distributing the materials to Cambodian university students. Our main results are as follows: (1) We can observe the embryonic duck's development using an incubator; (2) We developed new teaching materials for teaching evolution in Cambodian biology classes; (3) Students who use these teaching materials think that they are interesting and helpful for understanding evolution. Thus, we conclude that the developed teaching materials are very effective for teaching evolution in Cambodia.
\end{abstract}

$<$ Key words $>$ evolution, Cambodia, teaching materials

\section{Introduction}

Cambodia, officially the Kingdom of Cambodia, is a Southeast Asian country bordered by Thailand to the northwest, Laos to the northeast, Vietnam to the east, and the Gulf of Thailand to the southwest. With a total land area of $181,035 \mathrm{~km}^{2}$, Cambodia's location on the southern Indochina Peninsula gives it a tropical monsoon climate. The per capita GDP as of 2011 was $\$ 912$, and the economy is mostly driven by the textile, tourism, agriculture, and construction industries. Cambodia has a population of about 14 million, life expectancies of 56 years and 62 years for men and women, respectively, and infant mortality of 76 out of every 1000 live births. The official religion is Theravada Buddhism, which is observed by approximately $95 \%$ of the population, and the official language is Khmer.

Education in Cambodia follows the 6-3-3 system. Primary school and lower secondary school attendance is compulsory. However, while the enrollment rate in

\footnotetext{
${ }^{1}$ Yamamoto High School

${ }^{2}$ Nara University of Education
}

primary schools is $94 \%$, that at lower secondary schools is $34 \%$ and that at upper secondary schools is $16 \%$. The low rate of enrollment in secondary schools is because of the shortage of teachers and educational resources. Cambodia's literacy rate is $78 \%$ (Embassy of Japan in Cambodia 2013).

The Khmer Rouge regime of $1975-1979$ is a well-known chapter of Cambodia's history. The regime perceived education to be an obstacle to its ideal communist society, and arrested many of Cambodia's educators (Morimoto \& Maeda 2002). Additionally, most school buildings were destroyed or appropriated for other purposes and educational materials were burned.

The Japan International Cooperation Agency previously implemented the STEPSAM (Secondary School Teacher Training Project in Science and Mathematics in Cambodia (2000-2005), ISMEC (Project for Improving Science and Mathematics Education at Upper Secondary Level) (2006), and STEPSAM2 (2008-2012) programs. These programs comprised teacher training for secondary and higher education, science curriculum development, textbook development for high school science, and the introduction of planned lessons. As a result of 
this support, new science curricula were introduced in Cambodia for the following grades from 2007 to 2011: 2007-2008, Grades 1 and 10; 2008-2009, Grades 2, 4, 7, and 11; 2009-2010, Grades 3, 5, 8, and 12; and 20102011, Grades 6 and 9 (Ministry of Education, Youth and Sports in Cambodia 2005).

According to this system of curriculum reform, new curricula were being introduced in the upper secondary school until 2010. Before this time, the upper secondary school biology curriculum did not cover evolution, which is now a part of the reformed Grade 12 biology curriculum. Given that the previous biology curriculum did not cover this subject, we considered it likely that most of the teachers would want teaching materials on evolution.

We therefore endeavored to develop teaching materials for teaching evolution in Cambodian high school biology, with attention to using materials that can be easily acquired in Cambodia.

Wesolosky (2014) reports on the teaching materials utilizing Balut, which is the same material as this study. According to the report, one can observe the hatching process in 21 days. One can observe albumen, yolk, chalaza and the blastoderm three days after hatching and one can also observe yolk sac, the allantois and the amnion in five days. One can observe the limb buds. However, in this report, the relationship with the content of evolution is not mentioned, and neither is the response of the students.

We tried to develop the teaching materials for teaching evolution and get the response of the students for our developed teaching materials.

\section{The Cambodian educational curriculum on evolution}

The Cambodian high school curriculum on evolution is shown in Table 1. The chapter titled "The Evolution of Organisms" consists of three lessons: "Darwin's Theory", "Evidence of Evolution", and "The Fossil Record". From the similarities in structure, the chapter can be considered to be based on an American textbook (Michael J. Padilla et al. (2005).

\section{Selected teaching materials and textbook in Cambodia as the object of development}

"Darwin's Theory" mainly comprises reading materials. As for "The Fossil Record", because fossils are almost completely absent in Cambodia, students must rely on simulation activities with clay to study fossils. We believe that the observation of actual, rather than sim-

Table 1 Evolution in the revised Grade 12 biology curriculum.

\begin{tabular}{|c|c|c|}
\hline Contents & Objectives & Learning Outcomes \\
\hline $\begin{array}{l}\text { Chapter VI: } \\
\text { The Evolution of organisms }\end{array}$ & & \\
\hline Introduction & & \\
\hline $\begin{array}{l}\text { Lesson 1: } \\
\text { Darwin's Theory }(6 \mathrm{~h}) \\
\text { 1. Darwin's observations } \\
\text { 2. Galapagos's organisms } \\
\text { 3. Evolution } \\
\text { 4. Natural selection }\end{array}$ & $\begin{array}{l}\text { - Provide students with knowledge about } \\
\text { study of law of evolution of organisms. } \\
\text { - Instruct the basic skill of how to identify } \\
\text { the structure of ancient organisms. }\end{array}$ & $\begin{array}{l}\text { - Distinguish between the life on the } \\
\text { Galapagos Islands and the life on the } \\
\text { continent. } \\
\text { - Explain the research history of Darwin } \\
\text { and the interest in nature in his voyage. } \\
\text { - State the mechanism of evolution } \\
\text { containing variation and natural selection. }\end{array}$ \\
\hline $\begin{array}{l}\text { Lesson 2: } \\
\text { Evidence of Evolution ( } 6 \mathrm{~h}) \\
\text { 1. Interpreting the evidence } \\
\text { 2. Relationships among various species } \\
\text { 3. Origin of species }\end{array}$ & $\begin{array}{l}\text { - Provide the important concept of how to } \\
\text { change the character of an organism to } \\
\text { form a new species. } \\
\text { - Provide applications for better } \\
\text { understanding. }\end{array}$ & $\begin{array}{l}\text { - Explain the evidence of evolution based } \\
\text { on the fossil records, patterns of early } \\
\text { development, and homologous organs. }\end{array}$ \\
\hline $\begin{array}{l}\text { Lesson 3: } \\
\text { The Fossil Record ( } 6 \mathrm{~h}) \\
\text { 1. Fossil formation } \\
\text { 2. Determination of the age of fossils } \\
\text { 3. Advantage of fossils }\end{array}$ & $\begin{array}{l}\text { - Provide knowledge to students on the } \\
\text { record of fossils. }\end{array}$ & $\begin{array}{l}\text { - State the process of speciation. } \\
\text { - Determine a fossil's age based on } \\
\text { geological time scale, relative dating, and } \\
\text { radioactive dating. }\end{array}$ \\
\hline
\end{tabular}


ulated, phenomena should be developed and introduced to the Cambodian educational system. The "Evidence of Evolution" section contains discussion on homologous structures, which we considered a good lesson for developing activities to build students' observational skills. Therefore, we selected "Evidence of Evolution" as the lesson for which to develop teaching materials.

Figure 1 shows the embryonic development of various animals as given in a Cambodian high school textbook, and Figure 2 gives an English translation. In Cambodia, textbooks are published by the government rather than by a textbook company. This type of textbook layout, which contains a figure and the associated explanation, is thought to be readily understandable for Cambodian students. However, to increase understanding of the concept of homologous structures, suitable teaching material for this lesson is needed.

After deciding to focus our development of teaching materials on homologous structures, we were drawn to a popular Cambodian food, pong tia koon. This food, which translates word-for-word to "egg, duck, child", is a developing duck embryo that can be eaten at various stages of development (Figure 3). Pong tia koon is

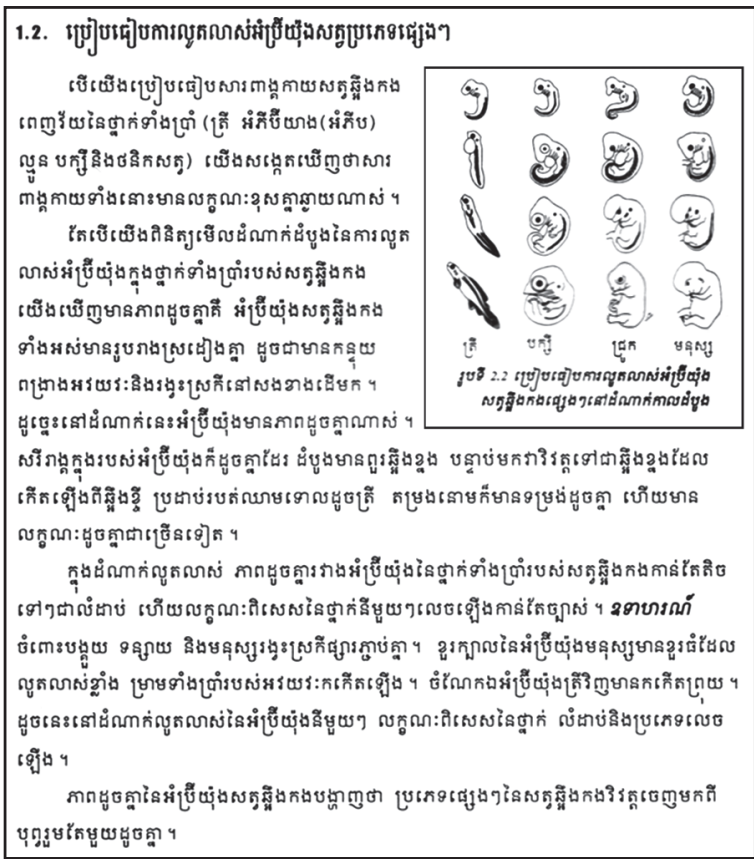

Figure 1 The embryonic development of various animals as explained by a Cambodian biology textbook. cheap, sold commonly at food stands, and much enjoyed in Cambodian cuisine. Students can easily observe the developing duck embryo inside the egg, which is easy to acquire locally.

Figure 4 shows the duck embryo in a pong tia koon egg, and the eye, beak, legs, and blood vessels are readily identifiable. Because we could observe these structures in the embryo, we considered pong tia koon suitable for the study of homologous structures in Cambodia.

\section{Making teaching materials for the observa- tion activity}

1. Materials: Fertilized duck eggs, incubator, petri dishes 2. Methods

(1) Fertilized duck eggs were put into the water in a petri dish at $39^{\circ} \mathrm{C}$.

(2) Fertilized duck eggs were rolled twice a day.

(3) From day 6 to day 13 post-fertilization, an egg was removed, boiled for 15 minutes, and observed

3. Obtained embryos and discussion

Figure 5 shows the obtained embryos from 6 to 13 days post-fertilization after boiling. We can identify the eye, wing primordium, leg primordium, tail, and blood vessels at 6 days post-fertilization. We also can confirm that the embryos are similar to the figure in the Cambodian upper secondary school textbook (Figure 1). Therefore, students would likely be able to understand the concept of homologous structures by observing this developing embryo. In addition to these identified structures, at 8 days post-fertilization the beak can be clearly identified, and at 9 days post-fertilization, the shape of

Compare the Development of embryo of various animals
If we compare the bodies of adult vertebrate animals of five classes (fish,
amphibian, reptile, bird and mammal), we observe that those bodies are far different.
But, if we examine at the first stage of embryonic development of five classes of
vertebrate animals, we see that three are similarities such as all embryo of vertebrate
animals have the similar shapes such as having limb drafting tail and gills flap at the
both side of the neck. Hence, at this stage, embryos are very identical.
In the development stage, similarities between the embryos of five classes of
vertebrate animals are very few gradually and special characteristics of each class
appear evidently. For example, for lizard, rabbit and human, gill flap is linked together.
The brain of human embryo has a big brain with strong growth and five fingers and toes
of the limb come out. And for the embryo of the fish, there is the growth of fins. Therefore,
at the stage of each embryonic development, special characteristics of class, level and
types are appeared. Similarities of vertebrate animal's embryo indicate that various
types of vertebrate animal evolve from the same origin.
Figure shows Fish, Bird, Pig and Human.

Figure 2 An English translation of the textbook shown in Figure 1. 


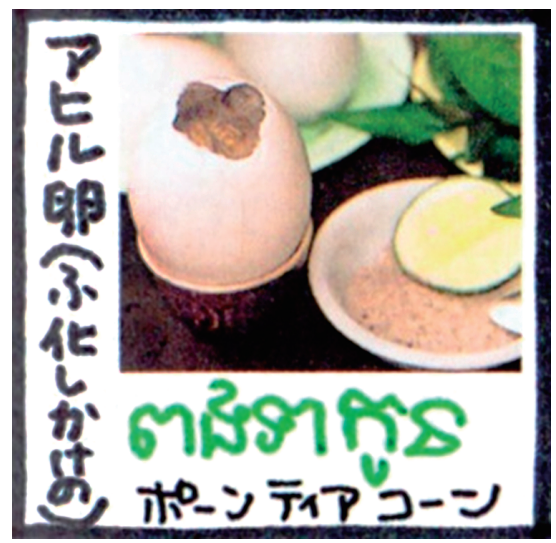

Figure 3 Pong tia koon displayed in a guidebook.

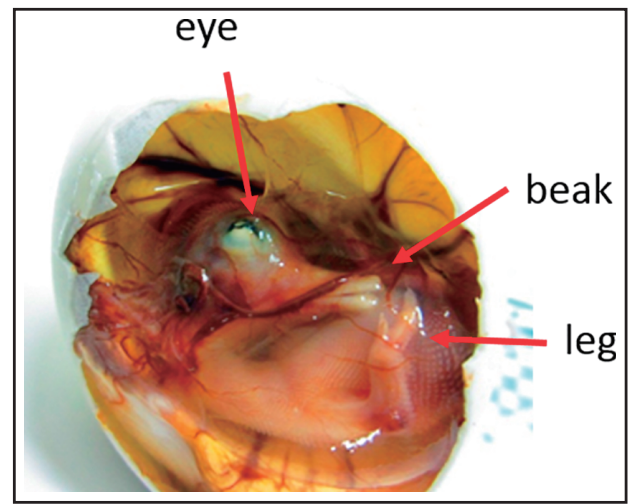

Figure 4 The inside of a pong tia koon egg at 13 days post-fertilization.

the head, wing, leg, and tail are even clearer. At 13 days post-fertilization, the duck's morphology has definitely emerged.

A Cambodian high school textbook explains homologous structures as follows (taken from Figure 2).

"If we compare the bodies of adult vertebrates of five classes (fish, amphibians, reptiles, birds, and mammals), we observe that they are very different. But, if we examine the first stage of embryonic development of these five classes of vertebrates, we see that there are similarities. All the vertebrate embryos have similar shapes, such as a limb developing into a tail and gill at both sides of the neck. So, at this stage, the embryos are very similar."

By using the images in Figure 5 and a Cambodian high school biology textbook, teachers will be able to instruct

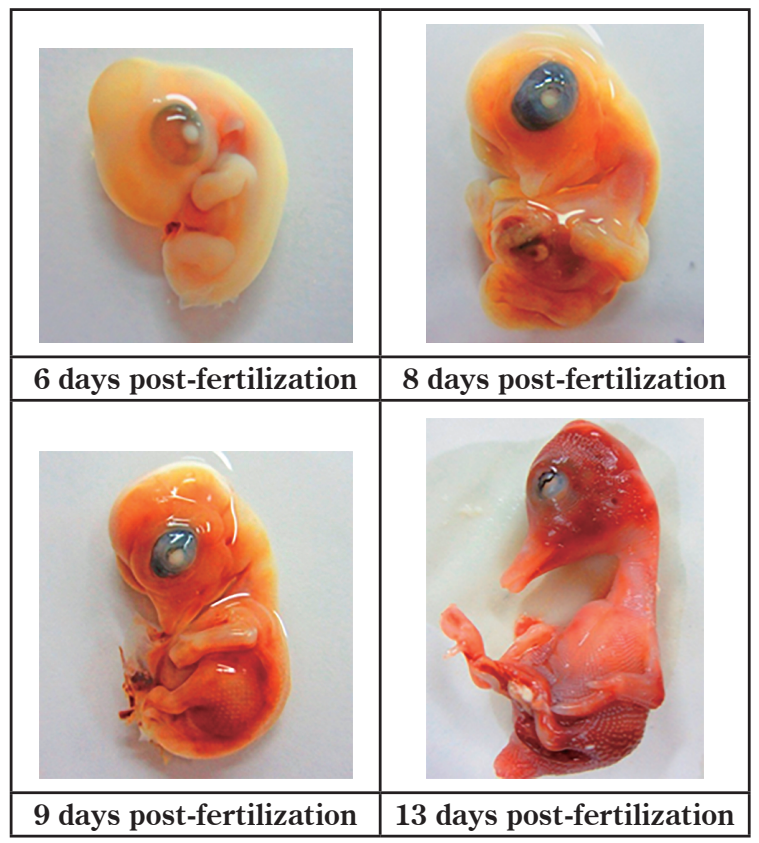

Figure 5 Embryos from 6 to 13 days post-fertilization after boiling.

students on how researchers infer evolutionary relationships by comparing the early development of embryonic specimens of different vertebrates. Moreover, students will be able to obtain the same results as in Figure 5 by obtaining pong tia koon themselves, allowing them to observe the embryos and compare with the figures in their textbooks firsthand. This will lead students to think about homologous structures and promote discussion about evolutionary theory.

Although in Japan it is difficult to acquire fertilized eggs, in Cambodia it is quite easy. Students can simply purchase pong tia koon at a food stand, and then observe the structures in the duck embryos themselves. Therefore, pong tia koon is a useful teaching material for the study of homologous structures in Cambodia.

\section{Developing teaching sheets for a classroom lesson}

Because most high schools in Cambodia do not have their own laboratory, it is difficult to prepare the embryos in the designated days post-fertilization. We developed teaching sheets for a classroom lesson to support the observational activity. The purpose of these teaching sheets is also to supplement the Cambodian high school biology textbook, as well as to help the teacher. 


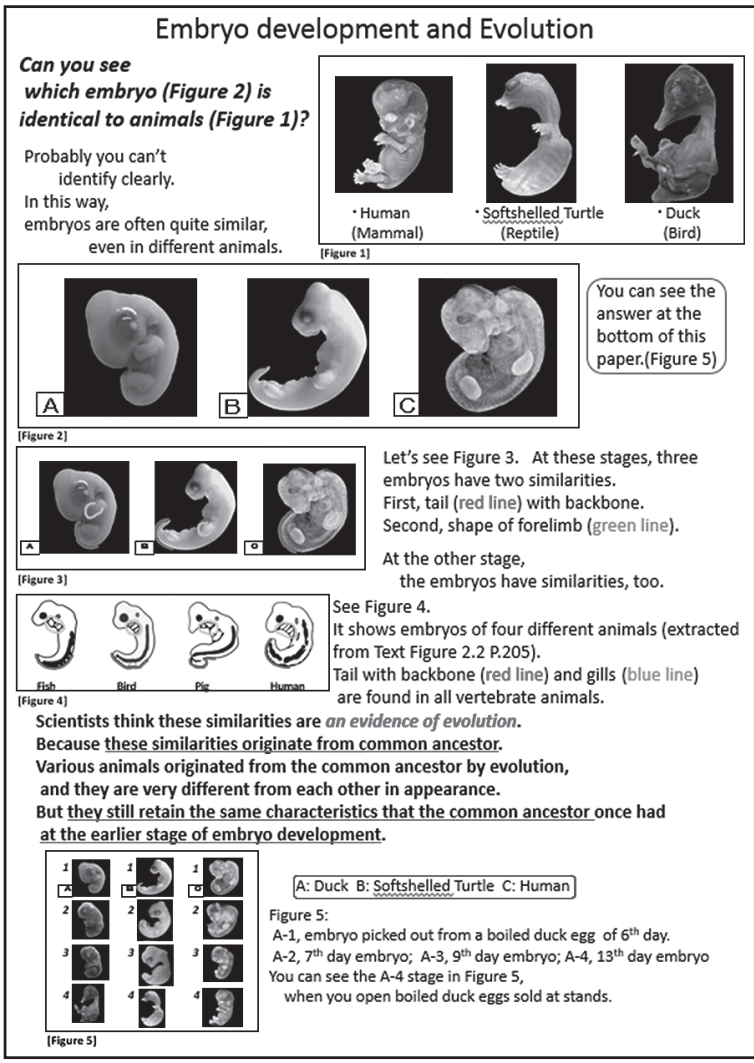

Figure 6 A teaching sheet developed for a lesson.

The developed teaching sheets contain figures and explanations. Figures include depictions of pong tia koon and explanations are given to expand on the Cambodian high school biology textbook.

In the Cambodian textbook, the embryonic development of a fish, bird, pig, and human are shown (Figure 1). Because pigs and humans are both mammals, only an actual photograph of a human was selected for our teaching sheet. A duck was selected as the representative bird embryo to most easily relate to pong tia koon. All the figures were created by us. In the case of the pong tia koon embryo shown on the teaching sheet, days after fertilization is indicated to enable students to easily observe the developmental stage in their own pong tia koon egg. The figures are arranged to correlate to homologous structures. The forelimbs and tail are described in the first half of the teaching sheet, and the backbone and gills are described in the second half. Gills are specifically included in the teaching sheet to correspond to the mention of gills in the Cambodian textbook.

When students observe the pong tia koon egg, it must be difficult for them to identify the organ in it at first. For example, they may not identify the eye, beak and the leg without the aid of the caption in Figure 4. It is considered that it is easier for students to identify the organs of the embryo based on the developed sheet.

\section{Examination of the effectiveness of the developed teaching sheets}

In order to examine the effectiveness of developed teaching sheets, a lesson was conducted as follows.

1. Objective: Twenty-seven students in Cambodian Mekon University

Their major is business and they did not study evolution in high school. It is very difficult to teach newly developed teaching materials to high school students in Cambodia. This is because most high schools cannot execute all the contents of the curriculum due to the shortage of teachers and teaching resources. Therefore, instead of high school students, University students were taught.

2. Date: 12 December 2012

3. Methods

(1) The students were divided into two groups.

Twelve students in Group A studied the lesson on evolution in the Cambodian high school biology textbook independently.

Fifteen students in Group B studied the lesson on evolution in the Cambodian high school biology textbook by themselves, with the developed teaching sheet.

(2) All students took a test on evolution after studying.

The contents of the test were as follows:

Q1. The position of the gills and tail in a human embryo

Q2. Explanation of the concept of homologous structures

(3) In order to evaluate the students' grasp of evolution, through the activities using the developed teaching sheet, two test items were designed that were based on the content of Cambodian textbook (Figure 1 and Figure 2).

Figure 7 shows the students studying by themselves.

\section{Results and discussion}

Figure 8 shows a sample student answer sheet. This student correctly answered the questions, correctly locating the gills and tail in the figure and accurately explaining the concept of homologous structures as evidence of evolution.

Figure 9 shows an example of wrong answer. This 


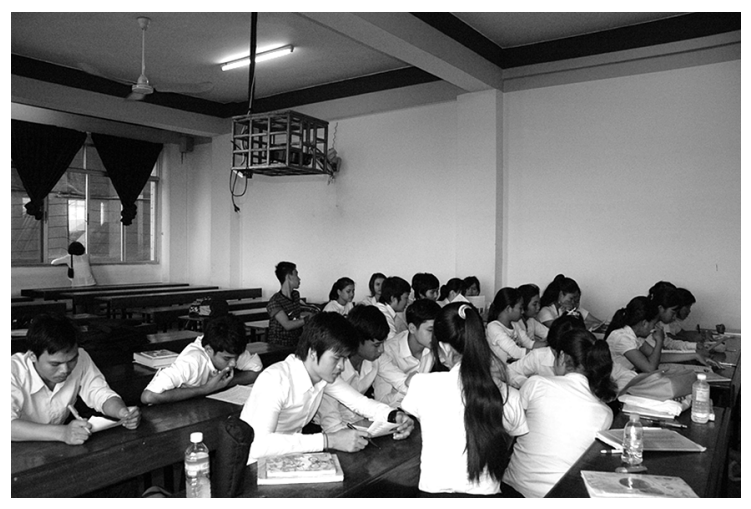

Figure 7 Cambodian students studying independently.

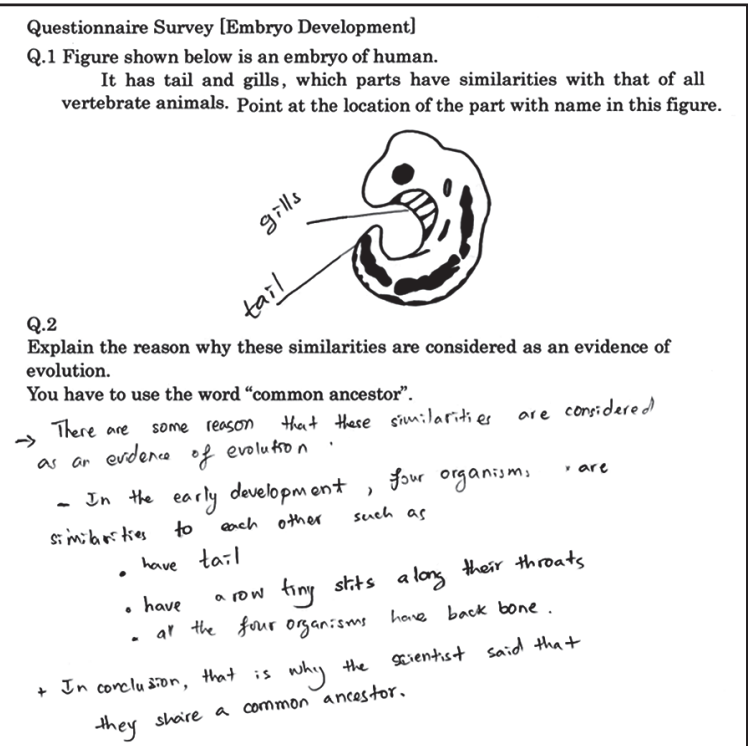

Figure 8 A student answer sheet in group B.

student could not understand the basic concept of evolution. The student answered that the evolution related the weather. And the student did not use the words "common ancestor" that were required in question 2.

Table 2 shows the class results of the test. For Question 1 most students in both groups correctly indicated the tail, but several students in Group A gave the incorrect answer for the gills. However, most students in Group B answered correctly. These results indicate that the developed teaching sheet is effective for this topic of study. However the difference between Group A and Group B is not significant according to the statistic test. T test are $1.81\left(\mathrm{P}_{0.05} 2.06\right)$ for Gills and $0.89\left(\mathrm{P}_{0.05} 2.06\right)$ for tail.

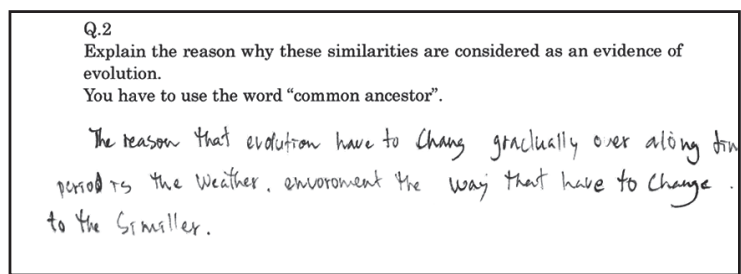

Figure 9 The other student answer sheet in group A.

Table 2 Test results for the class

\begin{tabular}{|c|c|c|c|}
\hline \multicolumn{2}{|c|}{} & A group 12 & B group 15 \\
\hline \multirow{2}{*}{ Question 1 } & Gills & $67 \%$ & $93 \%$ \\
\cline { 2 - 4 } & Tail & $100 \%$ & $93 \%$ \\
\hline \multicolumn{2}{|c|}{ Question 2 } & $0 \%$ & $13 \%$ \\
\hline
\end{tabular}

For Question 2, no students got the question correct in Group A. However, 2 students in Group B answered correctly. As Question 2 requires students to respond in a short answer format, which is an uncommon format in Cambodia, we believe it was very difficult for both groups of students, who may not have been able to answer due to the format. Additionally, the fact that the questions were written in English may have made answering more difficult. Though students can read English, it seemed that they could not understand exact technical details. The difference between Group A and Group B is not significant according to the statistic test. $\mathrm{T}$ test is $1.31\left(\mathrm{P}_{0.05} 2.06\right)$.

Overall, when comparing Group A students with Group B students, Group B students had the tendency to give the correct answer. Therefore, the developed teaching sheet seems to be effective for teaching lessons on evolution.

After the study, we asked a Cambodian lecturer at the National Institute of Education to translate the teaching sheet into Khmer, and the translated sheet is shown as Material 1 at the end of this paper. It is very difficult to translate the biological term into Khmer in Cambodia. In next study, we will revise the developed teaching sheet based on these results. Further, we will revise the teaching sheet in Khmer and examine the effectiveness of the teaching sheet in Khmer.

\section{Conclusion}

For this study, we developed teaching materials for teaching evolution in Cambodian schools. We made 
teaching materials for the observation activity by using pong tia koon and a teaching sheet to supplement the content on evolution in the Cambodian high school biology textbook. To examine the effectiveness of the developed teaching sheet, we distributed the sheet to Cambodia Mekong University students instead of high school students who may have already studied evolution. The university students' major is business and they had not previously studied evolution. Students that used the sheet could correctly answer questions on a test about evolution.

Thus, we conclude that the developed teaching materials are effective for supporting the Cambodian high school textbook's biology curriculum.

\section{Reference}

Embassy of Japan in Cambodia (2013) Retrieved from http:/ www.kh.emb-japan.go.jp/political/gaikyo.htm. 2014.05.26

Wesolosky, J. (2014). MIXED PLATE BIOLOGY, HAWAIIAN STYLE: BALUT EMBRYOLOGY, Roosevelt High School, Honolulu, HI 2014.0526

Morimoto, K., \& Maeda, M. (2002). Analysis of Upper-Secondary Biology Textbook in Cambodia. International Journal of Curriculum Development and Practice, 4(1), 31-38.

Padilla, M.J., et al. (2005) “Life Science” Prentice Hall 170-201. Ministry of Education, Youth and Sports in Cambodia (2005). A MASTER PLAN TO IMPLEMENT THE POLICY FOR CURRICULUM DEVELOPMENT 2005-09.

(2014 年 2 月 27 日受付, 2014 年 11 月 8 日受理) 


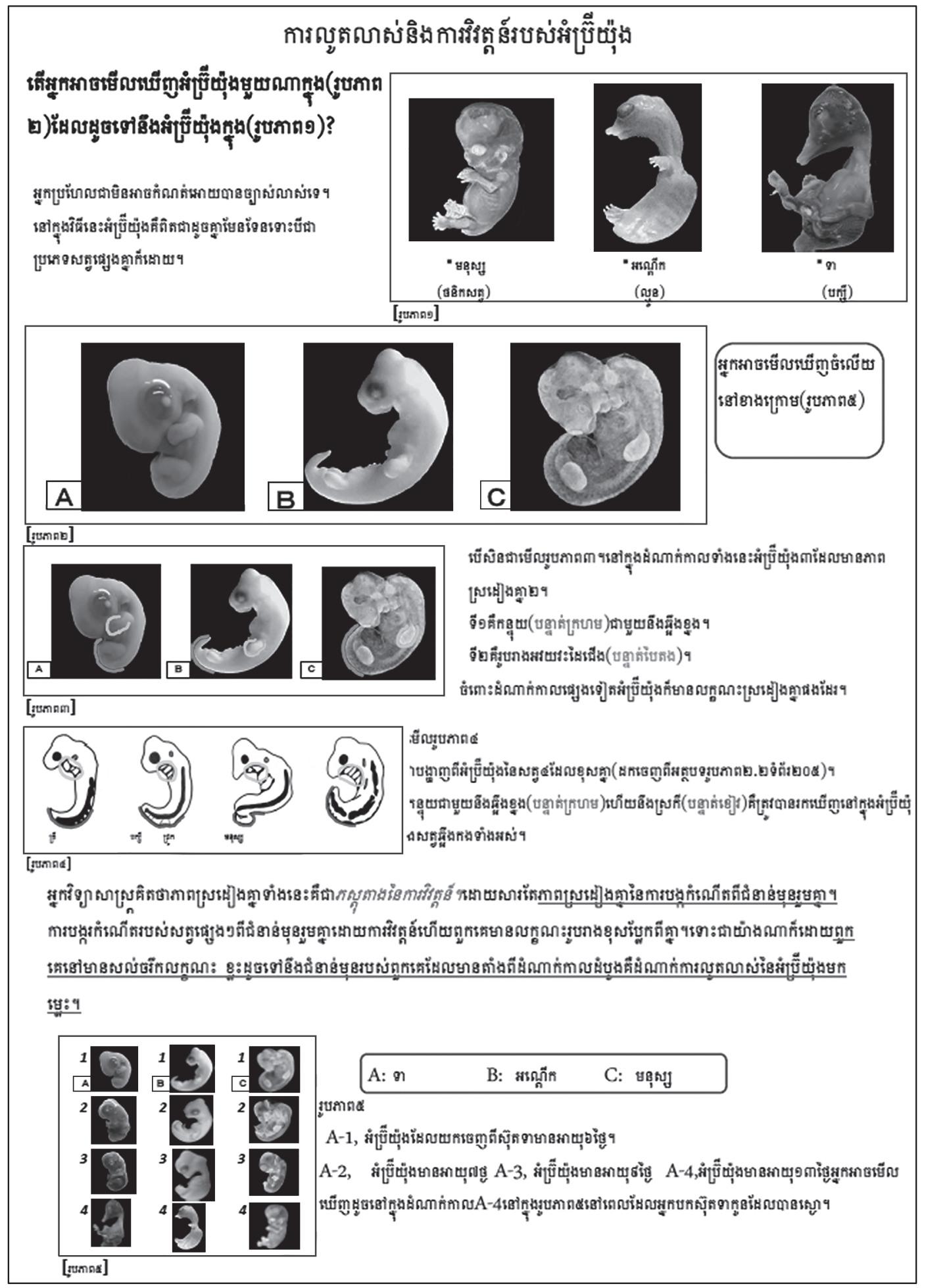

Material 1 A Khmer translation of the developed teaching sheet on evolution. 


\title{
カンボジアの高等学校生物における進化の教材開発
}

\author{
秋山兼太郎 ${ }^{1}$ \\ 森本 弘一 ${ }^{2}$
}

\begin{abstract}
【要
約】

カンボジアの新教育課程では, 高等学校生物において, 進化の内容が新しく導入された。 この論文は, カンボジアの高等学校生物における進化の教材を開発したことを報告するもの である。この開発した教材は, カンボジアで通常食べられているアヒルの卵の教材化を含ん でいる。開発した教材の有効性は, カンボジアの大学生を対象とした授業で検証された。得 られた知見は下記の通りである。

(1) 恒温器を用いてアヒルの卵の発生の様子を観察することができる。

（2）カンボジアの生物教育における進化に対する新しい教材を開発した。

（3）この教材を学習した学生たちは, この教材に興味を持ち, 進化に対して理解を深めた。 以上のように, 本研究で開発した教材は, 進化を学習するのに有効であると結論付けた。

[キーワード] 進化, カンボジア，教材
\end{abstract}

1 大阪府立山本高等学校

2 奈良教育大学 